Article

\title{
Effect of Sinkholes on Groundwater Resources in Arid and Semi-Arid Karst Area in Abarkooh, Iran
}

\author{
Božo Soldo ${ }^{1}$, Siamak Mahmoudi Sivand ${ }^{2} \mathbb{D}$, Ardalan Afrasiabian ${ }^{3}$ and Bojan Đurin ${ }^{1, *}$ \\ 1 Department of Civil Engineering, University North, 42000 Varaždin, Croatia; bozo.soldo@unin.hr \\ 2 Water Research Institute of Iran, Shiraz 0098, Iran; sivand57@yahoo.com \\ 3 Institute of Applied Geosciences, Graz University of Technology, 8010 Graz, Austria; \\ ardalan_afrasiabian@yahoo.com \\ * Correspondence: bojan.durin@unin.hr
}

Received: 2 February 2020; Accepted: 28 March 2020; Published: 31 March 2020

check for updates

\begin{abstract}
Despite protection measurements and their natural position, groundwater resources are very vulnerable due to natural and anthropogenic impacts. This is especially emphasized in karst arid and semi-arid zones, due to increased requirements for water. Paper deals with the impacts of the sinkholes on groundwater quality on Abarkooh city in Iran. There are 28 sinkholes located in Abarkooh plain. The aims of the paper are to specify the characteristics and causes of sinkholes occurrence, as well as to specify the vulnerable areas and future development of sinkholes and their effect on the groundwater resources. Next step is defining of the original procedure for protection of groundwater resources in characteristic areas, as karst arid and semi-arid areas are. By taking into the account geological, hydrogeological and meteorological data, and finally through hydrogeochemical and geophysical analysis, final conclusions and recommendations for the protection of the groundwater resources are obtained. This has significant importance for water supply of the Abarkooh city in Iran. It should be noted that the mentioned methodology for the protection of groundwater resources could be applied in other arid and semi-arid areas.
\end{abstract}

Keywords: karst; sinkholes; groundwater quality; protection measures; arid and semi-arid zones; Iran

\section{Introduction}

A sinkhole is a depression in the ground that has no natural external surface drainage [1]. They have very localized structural impacts but they may have far reaching effects on groundwater resources. Sinkholes can also have an impact on hydrologic systems, lakes, streams, and wet lands by changing water chemistry and rates of recharge or run-off [2,3]. Since the Earth's surface is constantly changing, sinkholes and other subsidence features will continue to occur with regards to both natural and human induced changes. Specific conditions can affect the type and frequency of sinkholes, including a general lowering of groundwater-levels, reduced runoff, and increased recharge or significant surface loading [4]. Recognition of these conditions is the first step in minimizing the impact of sinkholes. In areas underlain by cavernous limestone with thin to moderate thickness of overburden, increased sinkhole development and property loss are strongly correlated to human activity [5]. Land use changes in rapidly developing areas are often controlled and include drainage, new impoundments for surface water, and new construction in sinkhole prone areas. Finally, the changing land use is often associated with population increases and increasing demands for water supply, which may lead to an increase in ground water pumping capacity and the decreasing of local and regional groundwater levels [6].

Figure 1 shows the mechanism of occurrence of cover collapse sinkholes. 

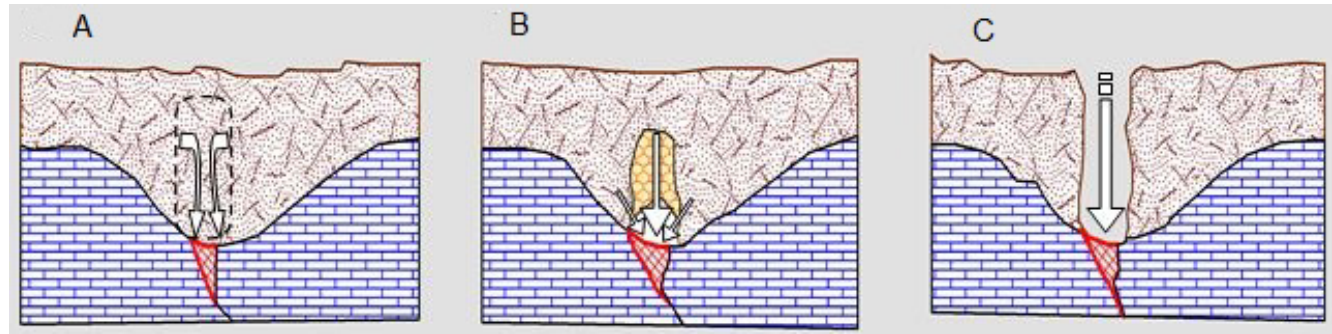

Figure 1. The mechanism of occurrence of cover collapse sinkholes. (A) existence of soil or non-continuous materials (units PlQc, PlQcm) or members with adhesive characteristics over the Oligo-Miocene limestones; (B) water flow washes soils over the karstic bedrock and transports it through big fractures into the underground parts; (C) the hole gets so big that the roof cave cannot bear the weight and collapse.

A cover-collapse sinkhole occurs when upper sediment is composed of soft materials, such as is clay. An underground cavity is created under the bedrock, so that some of the upper sediment falls into the empty space created by the cavity thereby weakening the topsoil gradually. The weakening upper sediment begins sinking and finally a sudden collapse occurs. Although the occurrence of a large size sinkhole can take a long period of time, the collapse occurs suddenly, so the damage caused can be serious.

Part A at Figure 1 presents existence of soil or non-continuous materials (units PlQc, PlQcm) or members with adhesive characteristics over the Oligo-Miocene limestones. There are several cracks and fractures in these limestones that can transport the sediments into deeper parts of the karst. The water movement is vertical in this section. Part B shows water flow washes soils over the karstic bedrock and transports it through big fractures into the underground parts. The karstic caves make the transportation of water and soil more easily. Water movement is horizontal in this section. In part $C$ it could be seen that eventually the hole gets so big that the roof cave cannot bear the weight and collapse.

Figure 2 shows the mechanism of occurrence of cover-subsidence sinkholes.
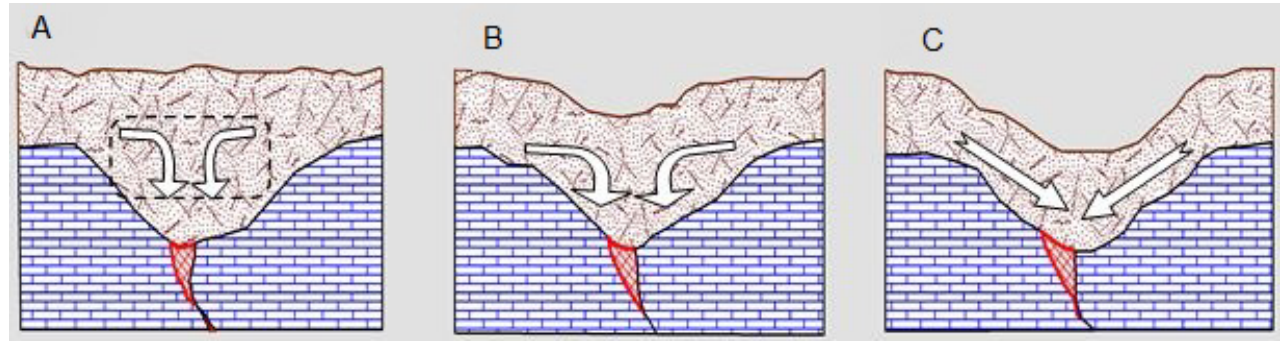

Figure 2. The mechanism of occurrence of cover-subsidence sinkholes. (A) existence of soil or non-continuous materials (units PlQc, PlQcm) or over the Oligo-Miocene limestones; (B) water flow washes soils over the karstic bedrock and transports it through big fractures into the underground parts; (C) continuous transportation of sediments through cracks and fractures, as well as the occurrence of the sinkhole.

Part (A) shows existence of soil or non-continuous materials (units PlQc, PlQcm) or over the Oligo-Miocene limestones. There are several cracks and fractures in these limestones that can transport the sediments into deeper parts of the karst. The water movement is vertical in this section. Low adhesion of surface makes the motion vector more horizontal compared with the previous case. From part (B) it could be seen that water flow washes soils over the karstic bedrock and transports it through big fractures into the underground parts. The karstic caves make the transportation of water and soil more easily. There is a continuous transportation of sediments through cracks and fractures, as well as the occurrence of the sinkhole at Part (C). 
A cover-subsistence sinkhole occurs in the form of small to mid-size holes. Many sinkholes of this type are generated in sandy soil where no viscosity is present in the surface layer, and it occurs mainly at a place where underground water is close to the ground. The subsidence occurs gradually rather than suddenly so sinking occurs gradually as well.

In last three decades, by growing agricultural activities, and accordingly increasing groundwater abstraction, land subsidence was reported from several parts of Iran. Frequent triggering factors in the development of land subsidence and sinkholes are overexploitation from groundwater aquifers, together with groundwater level fluctuations. Moreover, the existence of fine grain alluvium, tectonic features especially faults and dissolution of karst formations was reported as effective factors in the formation of sinkholes in Iran [7]. Authors in [8] have done research of the relationship between the declining groundwater level, land subsidence and sinkhole collapse in the Hamedan central plain in western Iran. Within this, the presence of fine-grained materials (for land subsidence) and karstic limestone bedrock (for sinkhole formation), increase of effective stress, and generation of turbulent groundwater flow at the soil-bedrock interface were investigated. The final result was a map of the hazardous regions. In paper [9], there was presented research of the impact of overexploitation of groundwater on occurrence of the sinkholes.

In general, underground water resources located in karst arid and semi-arid areas and issues about their vulnerability and protection were discussed and analyzed in the literature. Authors in [10] have conducted hydrogeological and hydrogeochemical study of a semi-arid karst aquifer in Tezbent plateau, Tebessa region, which is located northeast of Algeria. It has been shown that interaction between groundwater and surrounding host rocks is believed to be the main process responsible for the observed chemical characteristics of groundwater in the study area. Research provided by high resolution $\gamma$-spectroscopy, at the location of Nullarbor Plain in Australia by [11] has been shown that in undisturbed sites, little sediment movement has occurred over the time scale of Cesium-137 from the year of 1960, comparing with the year of the provided research. Although, lands have been well sought over a much longer time scale. In other words, such change is explained by the anthropogenic impact.

Hydrogeochemical researching is very common in the analysis of the underground water resources in karst arid and semi-arid areas. Authors in [12] provided "in situ" measurement of electrical conductivity (EC), $\mathrm{pH}$, water temperature, bicarbonates and anions in laboratory for the samples collected in the central part of the Cuddapah Basin of Southern India, which is karst arid area bigger than $100 \mathrm{~km}^{2}$. It has been shown that land use and anthropogenic effects are factors that likely lead to the variability in water chemistry of the underground water resources within karst semi-arid areas. Same conclusion was highlighted in paper [13] for the case study of the karst arid areas in Northern China.

Methodology very similar to the methodology (procedure) presented in this paper is an integrated approach to investigate the karst aquifer and clarify the factors, which affect the occurrence and quality of water contained therein, provided by [14]. This researching has been done in the northwestern arid coastal zone of Egypt, which is an accessible area attaining promising lands for agricultural expansion beyond the Nile Valley and Delta, by using isotopes, remote sensing and GIS applications. The main hypothesis of the study was based on conjecture that a portion of rainwater is thought to be infiltrated to the groundwater through joints and fractures, which can recharge the karst aquifer. Although most of the water levels in the drilled wells are under the sea level, the isotope analyses indicate that no contribution of seawater intrusion affects the groundwater, which was very unexpected, but a promising conclusion regarding usage of the underground water resources.

It is important to point out new research in arid areas of central Zagros Mountains [15], also very similar with researching presented in this paper. Researchers used isotopes data for determining the sources and elevations of the recharge area of the aquifer. Temporal variations of the isotopic data were compared with variations of electrical conductivity (EC). Unexpectedly, high EC was associated with a relative increase of discharge and depletion of $\delta^{18} \mathrm{O}$. The final conclusion is that recession of the discharge of karst springs after the rains is usually marked by increasing concentration of the 
solutes, which may negatively affect quality of the underground water resources. Authors in [16] made physical, chemical and hydrogeochemistry analysis of groundwater samples in Ardestan basin in the central Iran. All samples were analyzed for conductivity, dissolved oxygen, $\mathrm{pH}$, total dissolved solids (TDS), major cations, major anions and trace metals. Unfortunately, analysis conducted on the basis of major ion and trace element composition indicate that groundwater mostly falls under the status "unsuitable" not only for the drinking water supply, but also for the irrigation purposes.

Researchers proposed defining of the protection zones in their researching work [17], which was carried out for a large-scale managed aquifer recharge site in a semi-arid karst region in Jordan. The results divulge an extreme contamination risk resulting from livestock farming, arable agriculture and human occupation wide along the Wala dam surface catchment area of about $1770 \mathrm{~km}^{2}$, which is a 50 $\mathrm{km}$ south of Jordan's capital Amman. Such an approach is very effective, but it should be taken into the account that such measures imply a limitation of the human activity within protection zone areas. Interdisciplinary approach to the analyzed problem could be seen, for example, due to applying of the analytical hierarchical process (AHP) in [18], machine learning algorithm in [19], multicriteria methods in [20], etc. It can be concluded that the scarcity of water in karst arid and semi-arid areas as well as exacerbation presents serious problems in such areas. This is a motivation for creating and presenting of a new procedure and researching methods for solving a problem of the quality and quantity of the groundwater resources in arid and semi-arid karst areas.

\section{Materials and Methods}

\subsection{Methodology}

Paper will analyze hydrological and hydrogeological characteristics, as well as the quality of the underground water in the location of the 28 sinkholes located in the north-west of Feizabad village, near Abarkooh city in Iran. This is done for the purpose of removing and preventing the deterioration of drinking water quality in analyzed area. Within this, the paper will present and explain all parts of the original procedure for protection of the underground water resources in arid and semi-arid areas. This procedure consists of determining and analysis of the geological, hydrogeological and meteorological characteristics of the observed area in the first stage of the analysis. The next stage contains geophysical and geochemistry researching with regards of the observed and provided researching at the first stage of the methodology. The final stage provides conclusions and recommendations for protection measures of the underground water resources in karst arid and semi-arid areas. The resented procedure is an extension of the all current researching made for the karst arid and semi-arid areas. Such methodology could be applied in all locations where karst arid and semi-arid areas exists.

\subsection{Study Area with Geological, Hydrogeological and Meteorological Characteristics}

Abarkooh city is located in the south-eastern city of Yazd province in Iran, Figure 3. Abarkooh plain, with an area of approximately $2000 \mathrm{~km}^{2}$ and an altitude of about $1446 \mathrm{feet}$, is a dry plain. The maximum temperature recorded in the region is $43^{\circ} \mathrm{C}$, while the minimum temperature is $-12{ }^{\circ} \mathrm{C}$. The average annual temperature in the area is $19^{\circ} \mathrm{C}$. The average rainfall in the area is $63.4 \mathrm{~mm}$, and according to a 10-year period (2000-2010), the annual maximum rainfall is equal to the 122.1 $\mathrm{mm}$ [21]. Pliocene-Quaternary clastic units cover a wide area of Abarkooh plain. Sinkholes are located in Pliocene-Quaternary units, which consists of alternation of conglomerates, marls, clays and silt. The bedrock is made of karstic Oligo-Miocene limestone in northern parts. The existence of Pliocene-Quaternary clastic units in the surface and the limestone bedrock means this region is a vulnerable area for development of the sinkholes.

Position and location of the sinkholes and sampled wells (WS) is marked on Figure 4 [23].

There are 28 sinkholes located in the north-west of Feizabad village. A compass, GPS and the measuring line were used in this research. According to geology maps, sinkholes are located in PlQc, PlQtr1 and PlQcm units, Figure 5. The local inhabitants are unaware of the start date of these sinkholes, 
yet another local group of inhabitants acknowledge that the sinkholes occurred in the direction of the local river. Due to this, sinkholes every year create the channel path, which is lately filled by the sediments.

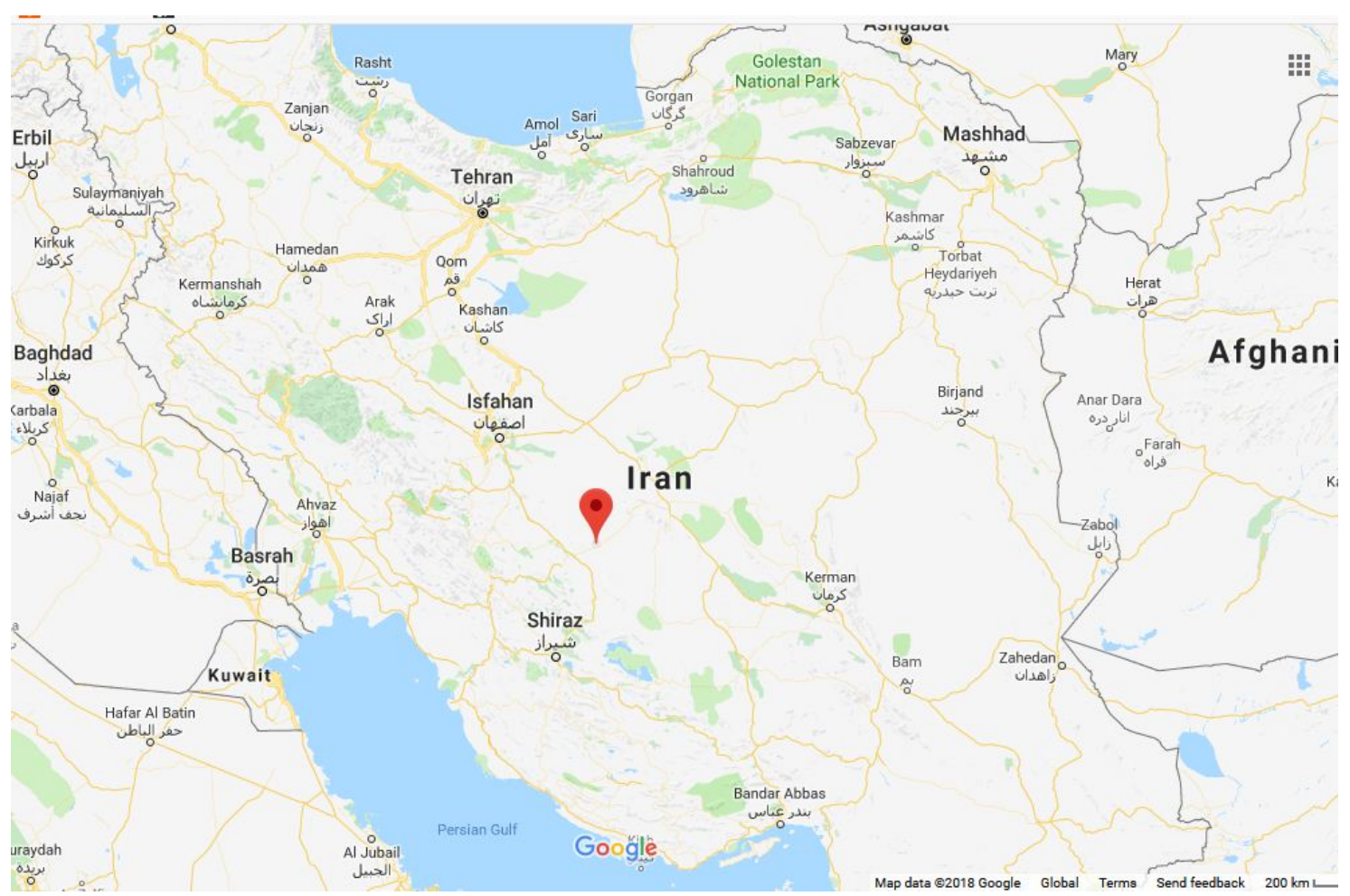

Figure 3. The location of Abarkooh city [22].

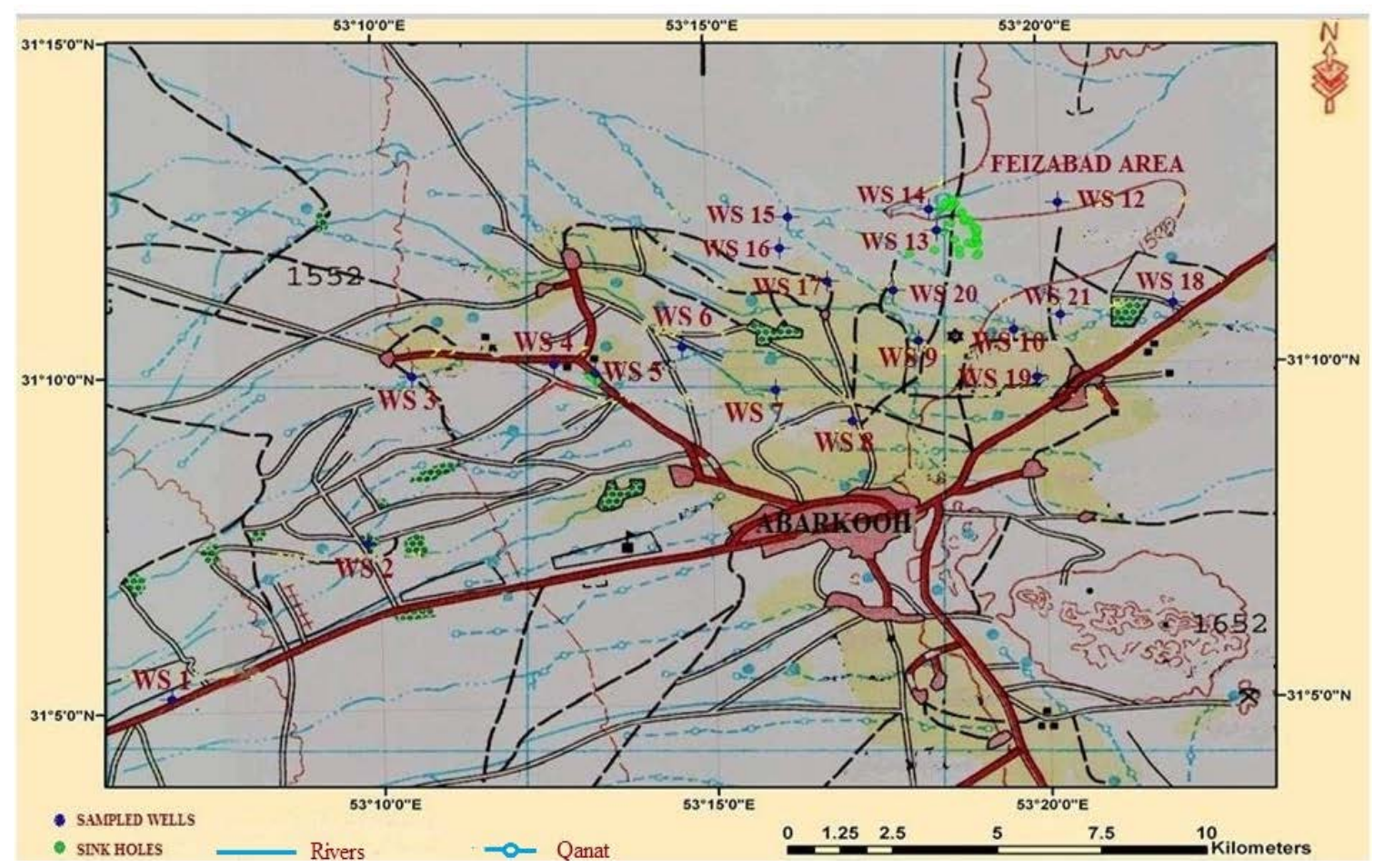

Figure 4. Position and location of the sinkholes and sampled wells. 


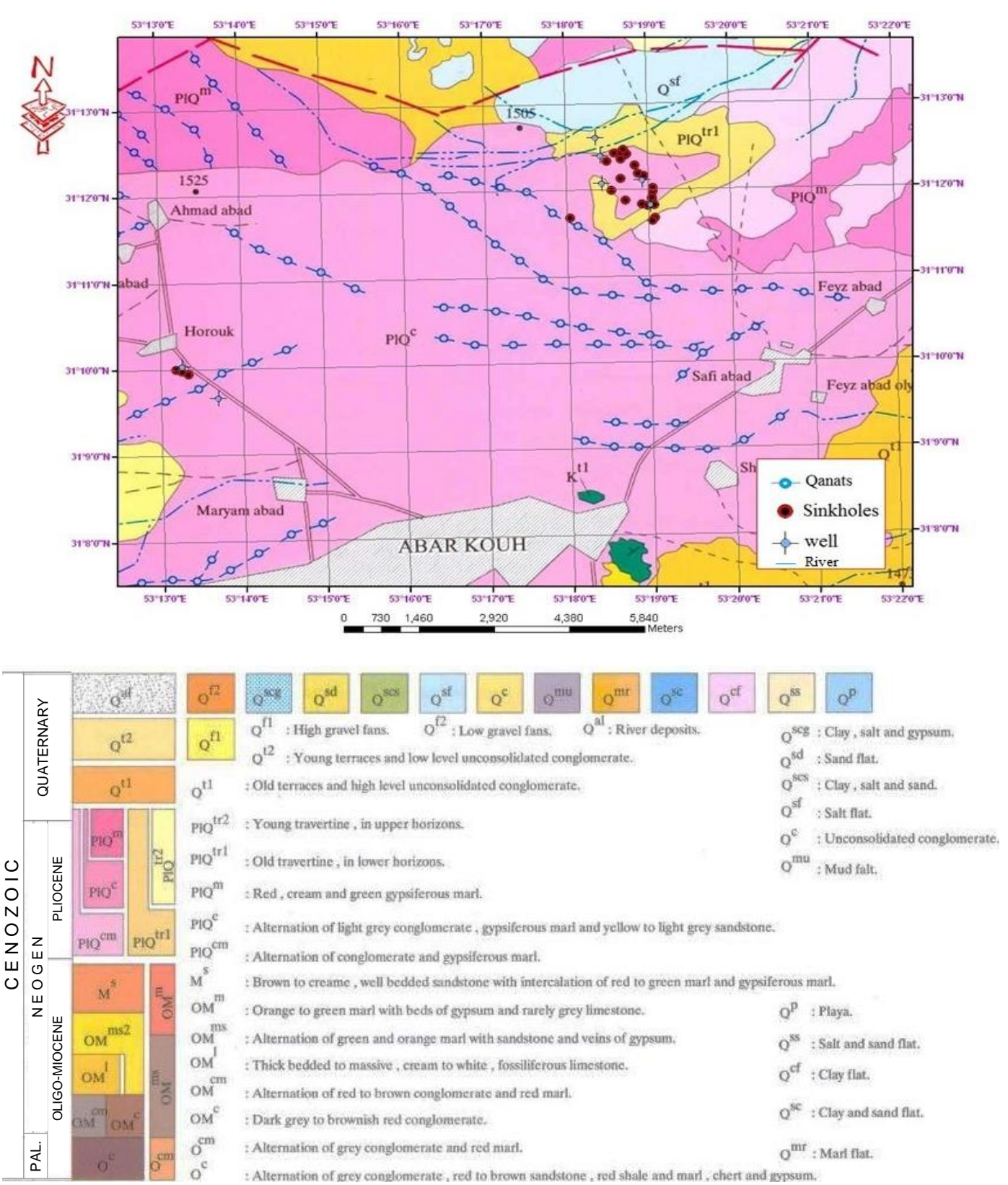

Figure 5. Detailed view of the location of sinkholes with geological map around sinkholes near Feizabad [23].

According to the field investigation, all of Abarkooh sinkholes were located in karst. The types of sinkholes were subsidence sinkholes and collapse sinkholes. According to the field data, sinkhole $\mathrm{S} 13$ with the biggest depth of $13.5 \mathrm{~m}$ was the most significant sinkhole in the area. Additionally, there were some sinkholes with smaller diameters and depth, compared with the above mentioned. So, the surface water infiltrated through these sinkholes and come to the groundwater. In fact, these sinks act as drainage for surface water in the area. The existence of cohesive soils and deep flows increased water velocity in the horizontal and vertical directions. Consequently, the transported sediment made holes on the boundary between the bedrock covering layer. While holes become bigger, the roof strength decreased and eventually suddenly collapsed, Figure 5 [23]. The groundwater level dropped, while the concentrating river flows could lead to the faster creation of sinkholes. Important factors in the formation of sinkholes are groundwater level drops, artificial recharge, bedrock fractures and surface covering thickness. Figure 6 shows a decrease of the total precipitation of the Abarkooh plain 
from April 1983 to September 2008. Reduction in groundwater levels, in areas in which all voids are already filled with water, can lead to the recharge of aquifer from surface [24]. Amounts of water flow in this area are high due to the motion of surface water from highlands to lowland areas. Reduction in groundwater levels and increasing of exploitation has destroyed the buoyant support in the ceiling of cavities in the bottom of the bedrock in a higher amount than water has been done before.

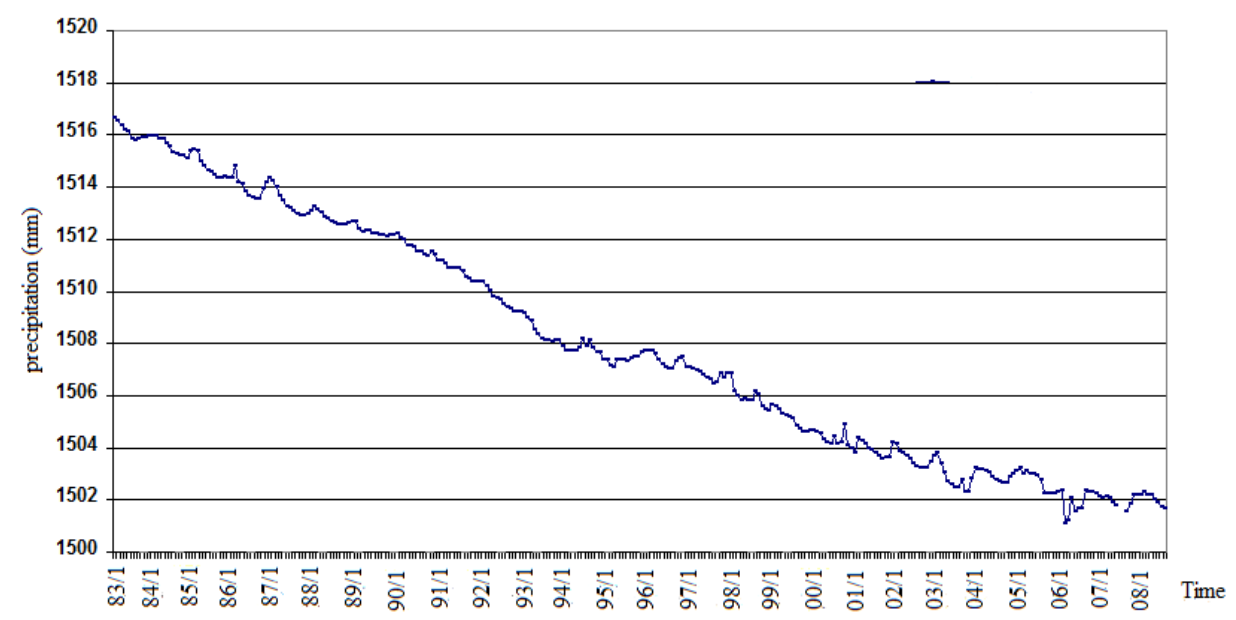

Figure 6. The precipitation amount of the Abarkooh plain from 1983 to 2008 [21].

Figure 7, part A, shows the concentration of surface waters and centralized subsidence. Part B presents forming of a devastating hole, while part $C$ shows the development of the cavity and the transfer of more surface material to the depths part. On part D, subsidence and expanding the effective range on the main cavity could be seen. Part E shows the collapse and occurrence of the sinkhole.

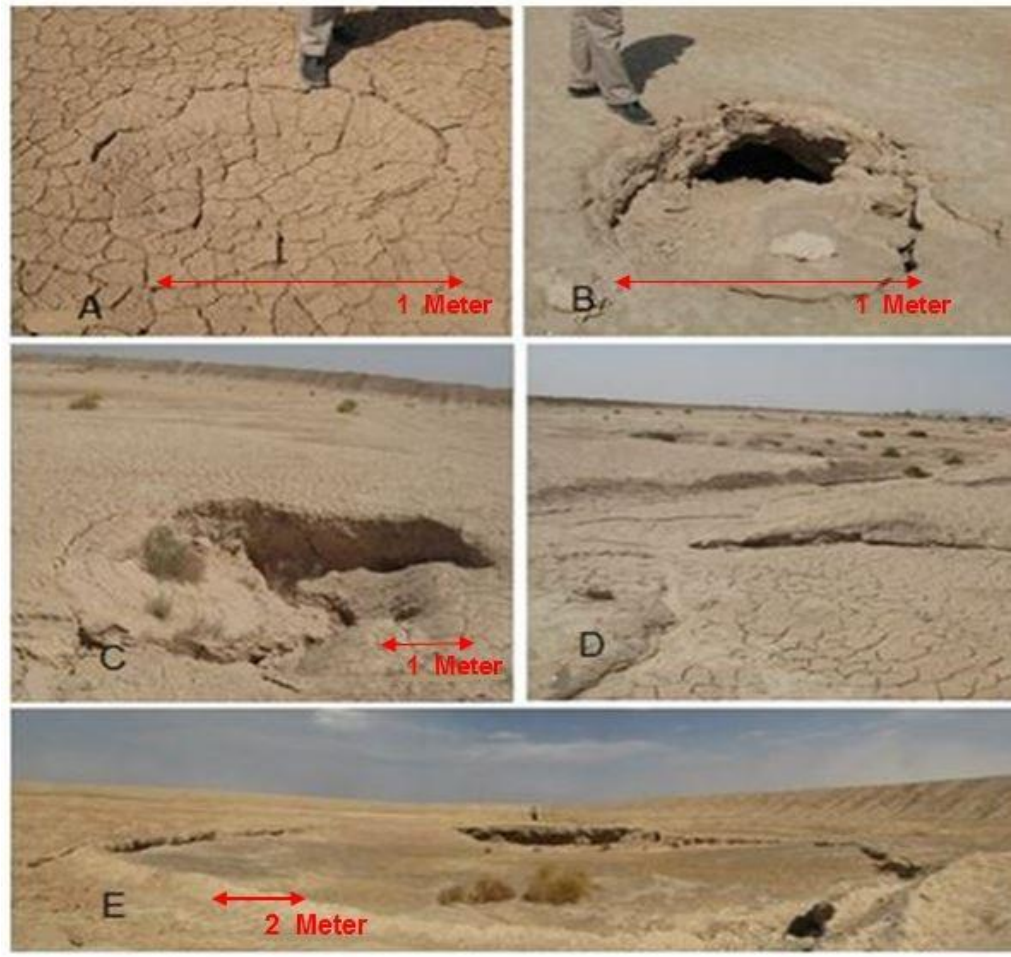

Figure 7. The process of occurring of sinkholes near Feizabad. (A) concentration of surface waters and centralized subsidence; (B) forming of a devastating hole; (C) development of the cavity and the transfer of more surface material to the depths part; (D) subsidence and expanding the effective range on the main cavity; (E) collapse and occurrence of the sinkhole. 


\section{Artificial Recharge and Chemical Constituents in Sampled Surface Water}

In recent years, some locals made embankments around the area in order to increase the discharge of their wells. The embankments caused greater concentration of the chemical constituents and bigger amount of the transport of surface water into the ground. It is noticeable that all of the sinkholes in the North West of Feizabad are located within these embankments area range, while bigger concentration of the chemical constituents, as well as the distribution of sinkholes are around the embankments walls (Figures 8 and 9) [23].

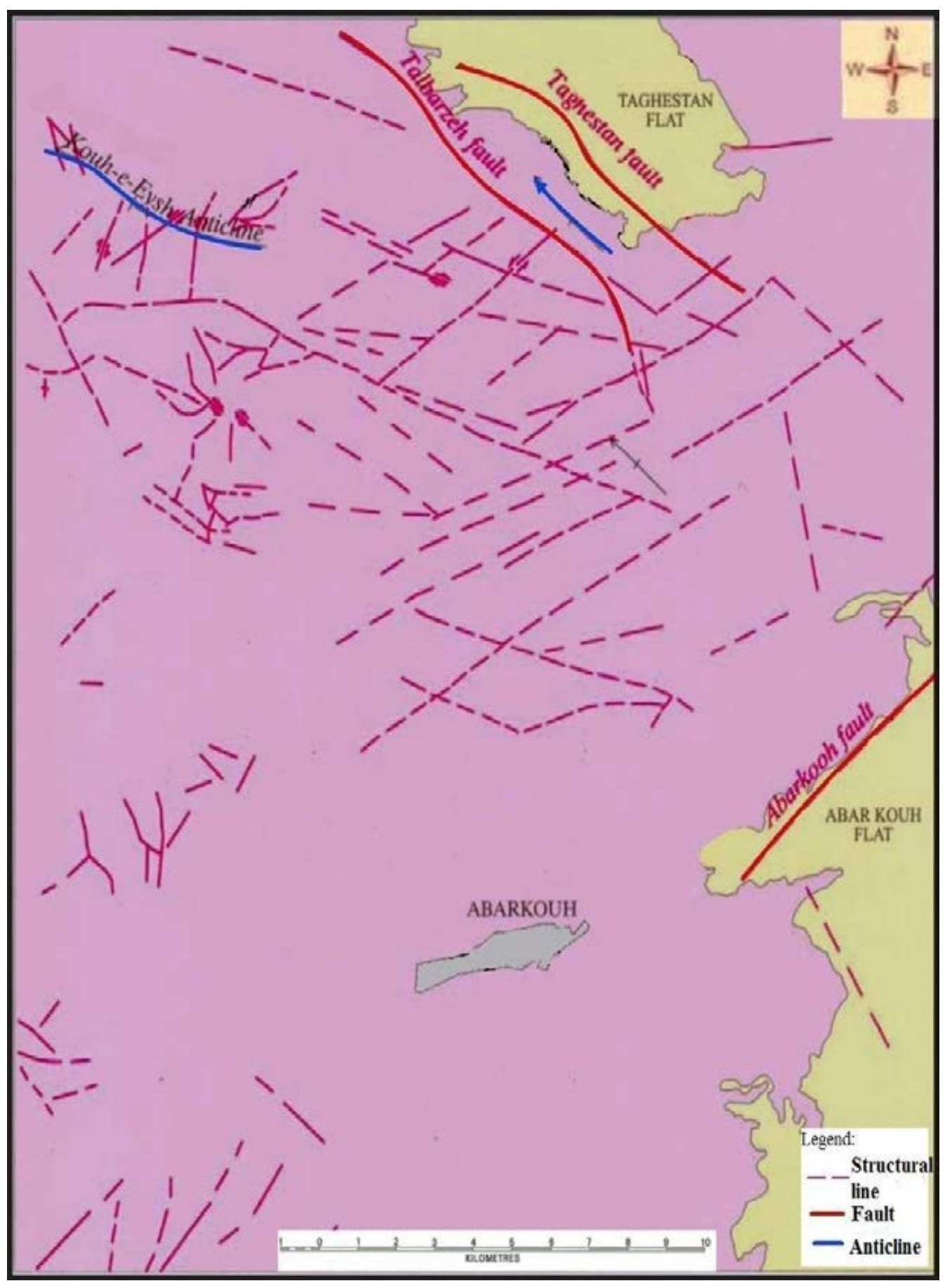

Figure 8. Structural map of the area. 


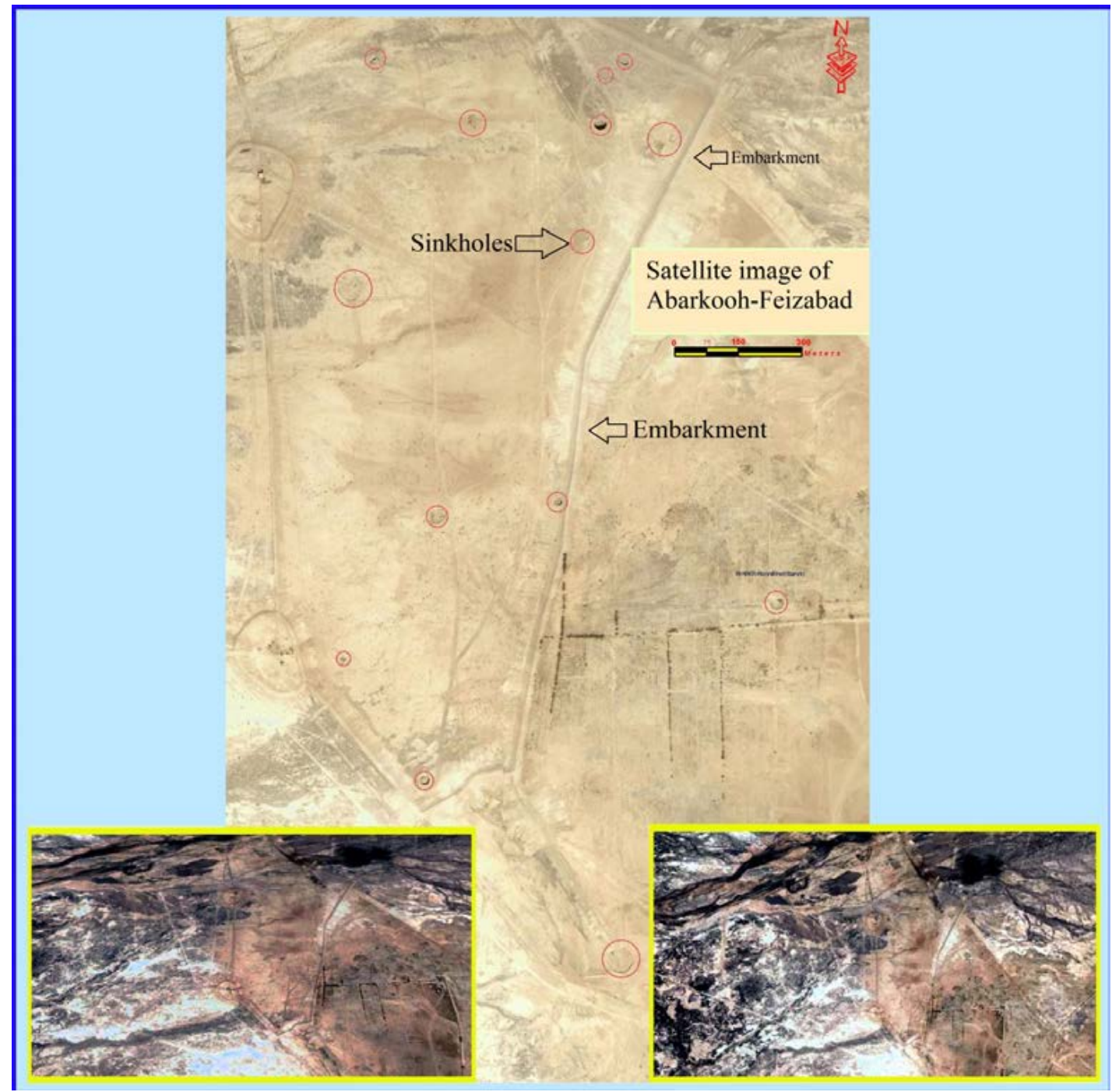

Figure 9. Satellite images of some of the sinkholes near Feizabad.

\section{Bedrock Fractures and Thickness of Surface Cover}

The bedrock fractures can role an important factor in the development of karst phenomena [7]. However, if the thickness of the sedimentary cover is low, the role of surface water in transportation of the sediments into cavities is higher. According to geoelectrical profiles (Figure 10), the thickness of the sedimentary cover of areas, in which there are fractures in their bedrocks, were lower because of the bedrock faults. Between points 48 and 51, there is located a lower layer with a very small rock resistivity of 6-10 Ohm at an approximate depth of $20 \mathrm{~m}$, which is very likely to belong to the Oligo-Miocene sediments. Due to the probable fault function in the range of point 52 , the thickness of alluvial deposits at this point is less than $20 \mathrm{~m}$.

Undoubtedly, if the other factors in the occurrence of sinkholes in this area were provided, this area had the potential for the occurrence of sinkholes (Figure 11).

It could be seen that the sinkholes occurred between 48 and 51 points in J profile. Dangerous positions imply potential location for occurring of the new sinkholes.

In profile J of geoelectrical profiles, between points 48 and 51, the thickness of surface covering becomes $20 \mathrm{~m}$, because of the bedrock fault (Figure 11). This factor along artificial recharge was the important factor in the occurrence of sinkholes in the observed area. 


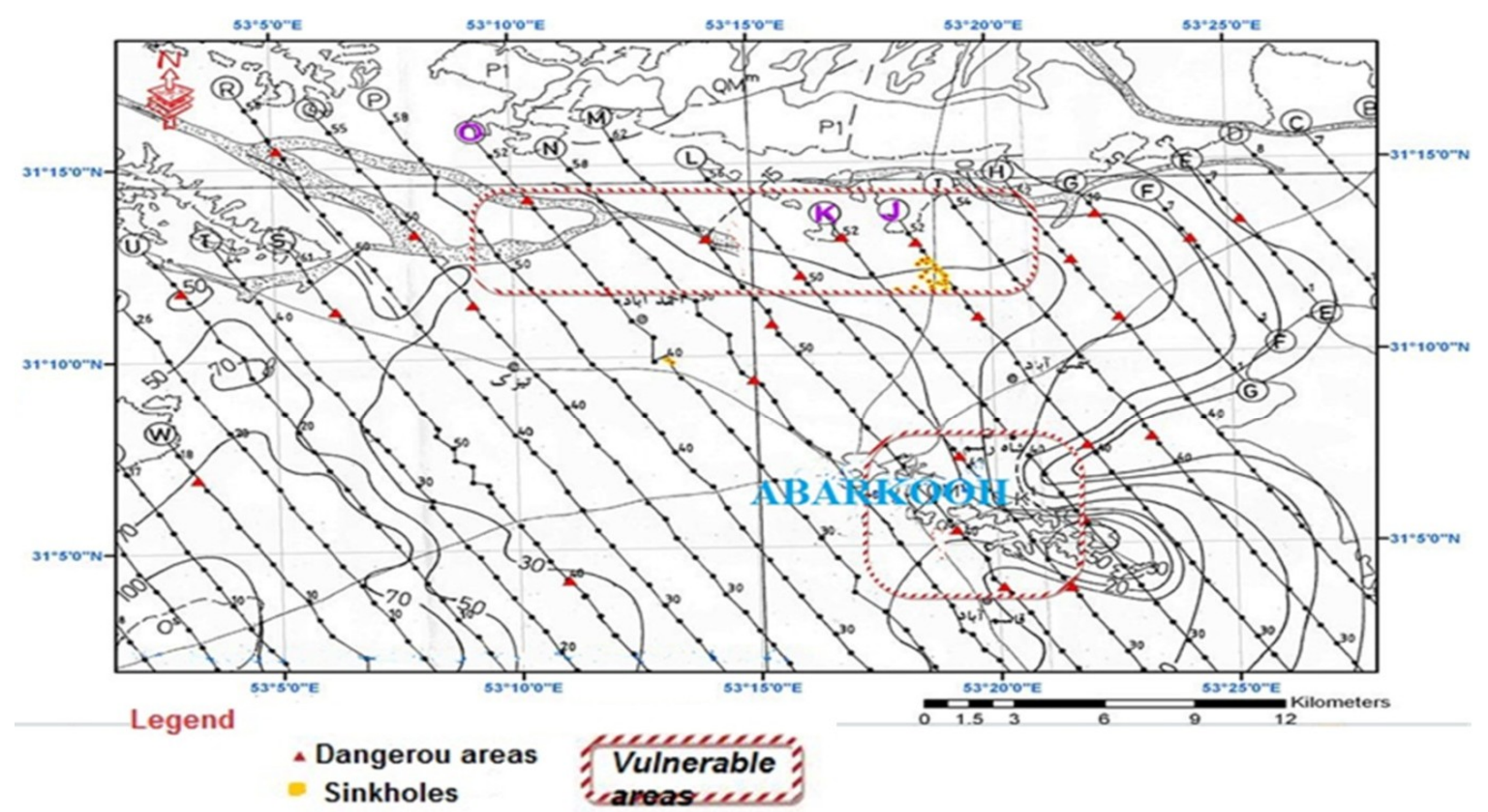

Figure 10. Geoelectrical profiles in Abarkooh plain and vulnerable areas. The sinkholes occurred between 48 and 51 points in J profile. Dangerous areas imply the potential location for occurring of the new sinkholes.

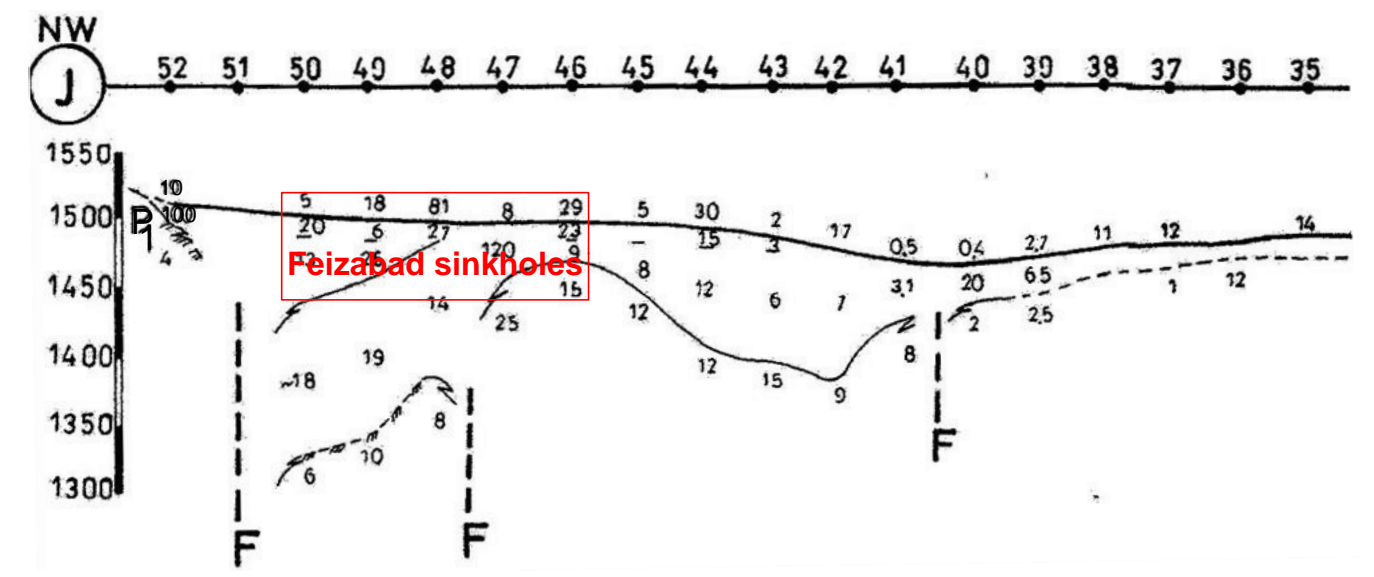

Figure 11. Cross section of the J profile-Feizabad area.

\section{Vulnerable Areas for Future Sinkholes}

For predicting of the vulnerable area for future sinkholes, which could appear, important factors should be prioritized according to the current conditions. These are the existence of limestone bedrock, as well as concentration points, where water from rivers and surface waters could enter into underground structures. Bedrock fractures and development of karst phenomena are also included as an important factor.

The bedrock in northern part of Abarkooh plain is made of Oligo-Miocene formations. River located in the northern part of the Abarkooh plain has an effective role in the forming of floods in the area. Therefore, in these areas sinkholes are likely to occur if there is an infiltration of the surface water. The operation of faults in bedrock, in addition of the development of karst and dissolution in limestones, and also with lifting of bedrock causes reducing the thickness of surface covering. The northern part of the Abarkooh plain and Abarkooh City have more deep fractures (critical area), therefore the possibility of occurrence of sinkholes are higher in mentioned areas. 
To determine the quality of groundwater and sinkholes role, 20 wells were sampled by the bailer. The collection of water samples from groundwater wells occurs in five steps: sampling preparations, accessing the well before sampling and securing the well after sampling, measuring the water level, purging the well, and collecting with delivering of the water sample, in June 2010 in the Abarkooh Plain. Based on the experimental results, the most important type of groundwaters were Chloro-sodic, except well No 6, because of the existence of salty layers. The type of groundwater in well 6 is sulfate-sodic. The ionic frequency in cations are $\mathrm{Na}+\mathrm{K}>\mathrm{Mg}>\mathrm{Ca}, \mathrm{Na}+\mathrm{K}>\mathrm{Ca}>\mathrm{Mg}$, and in anions are $\mathrm{Cl}>$ $\mathrm{SO}_{4}>\mathrm{HCO}_{3}, \mathrm{Cl}>\mathrm{HCO}_{3}>\mathrm{SO}$. According to the statistical characteristics of the different chemical elements-in terms of meqv/gL, which is the range of total sodium and potassium cations, as well as of the chloride anions are higher than other ions. The range of electrical conductivity is in the range until $4659 \mu \mathrm{S} / \mathrm{cm}$. Water quality for agriculture has fluctuated from "salty-usable for agriculture" to "very salty-unsuitable for agriculture". In the classification of water quality based on the hardness, samples are located in the range of "hard" and "very hard". The electrical conductivity of the plain varies in the range between 1300 and $5000 \mu \mathrm{S} / \mathrm{cm}$, Figure 12 [23].

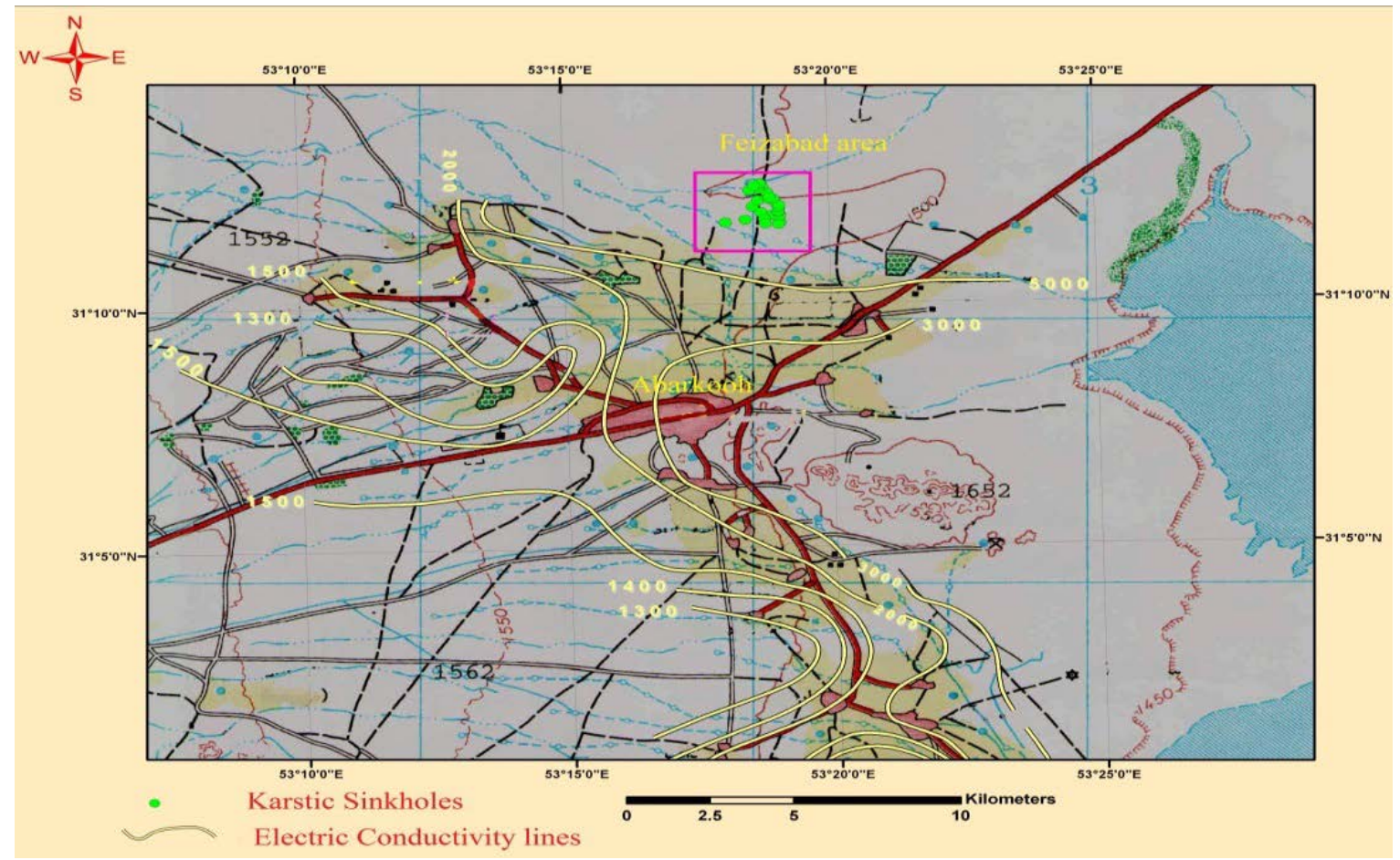

Figure 12. Electric conductivity lines of groundwater sources in the Abarkooh plain from 2000.

In the central and south eastern area of the plain, an increase in groundwater electrical conductivity was observed, while in the north east region (District Feizabad) there was a significant decrease in electrical conductivity. It seems that the role of sinkholes in the aquifer charge prevents the increase in electrical conductivity from the west to the east. By comparing the electrical conductivity maps in 2000 with recent maps, it appears that the role of the sinkholes in the aquifer recharge in the area was more prominent. In other words, the creation of embankments and development of the sinkholes, in order to aquifer recharge, led to changes of the trend of increasing groundwater electric conductivity in the region.

Lines of chloride, nitrate and nitrite (Figures 13-15) show that there is an increase of water quality in Feizabad, due to the recharge from sinkholes. In accordance with the standard by EPA [25], the rate of nitrate in drinking water can be $10 \mathrm{mg} / \mathrm{L}$, which is an acceptable standard, and can be a maximum of $50 \mathrm{mg} / \mathrm{L}$. According to this, the standard maximum level for nitrite in drinking water is $1 \mathrm{mg} / \mathrm{L}$. Thus, the nitrite in the water of the Abarkooh plain is in the standard range, but the level of 
nitrate is higher than the standard value. It should be noted that nitrate and nitrite ions arise from anthropogenic activities.

Tables 1 and 2, show the chemical analysis of all other chemical parameters for the selected wells in the Abarkooh plain [23].

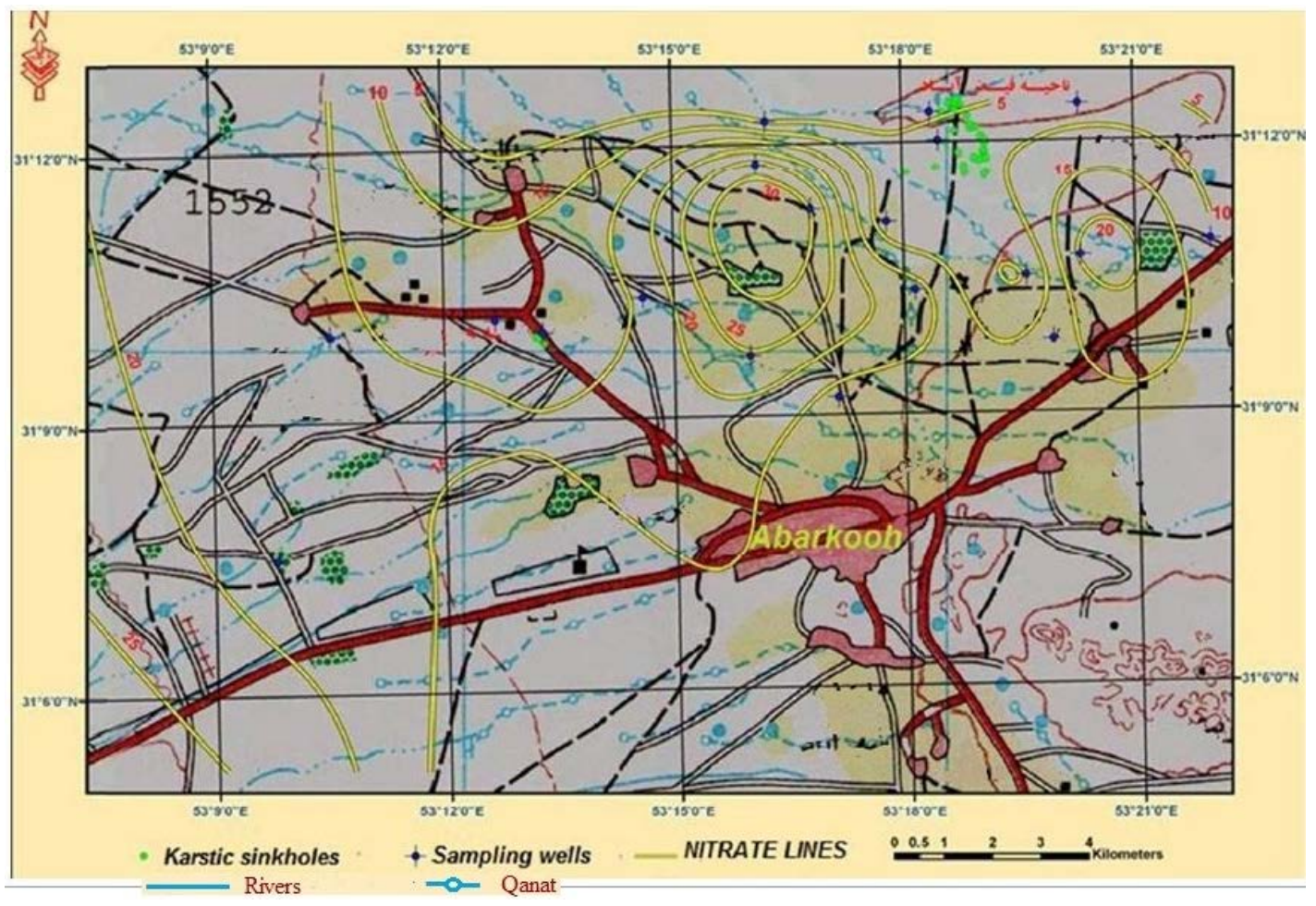

Figure 13. Contour lines of the nitrate concentrations in groundwater in $\mathrm{mg} / \mathrm{L}$ in the Abarkooh plain.

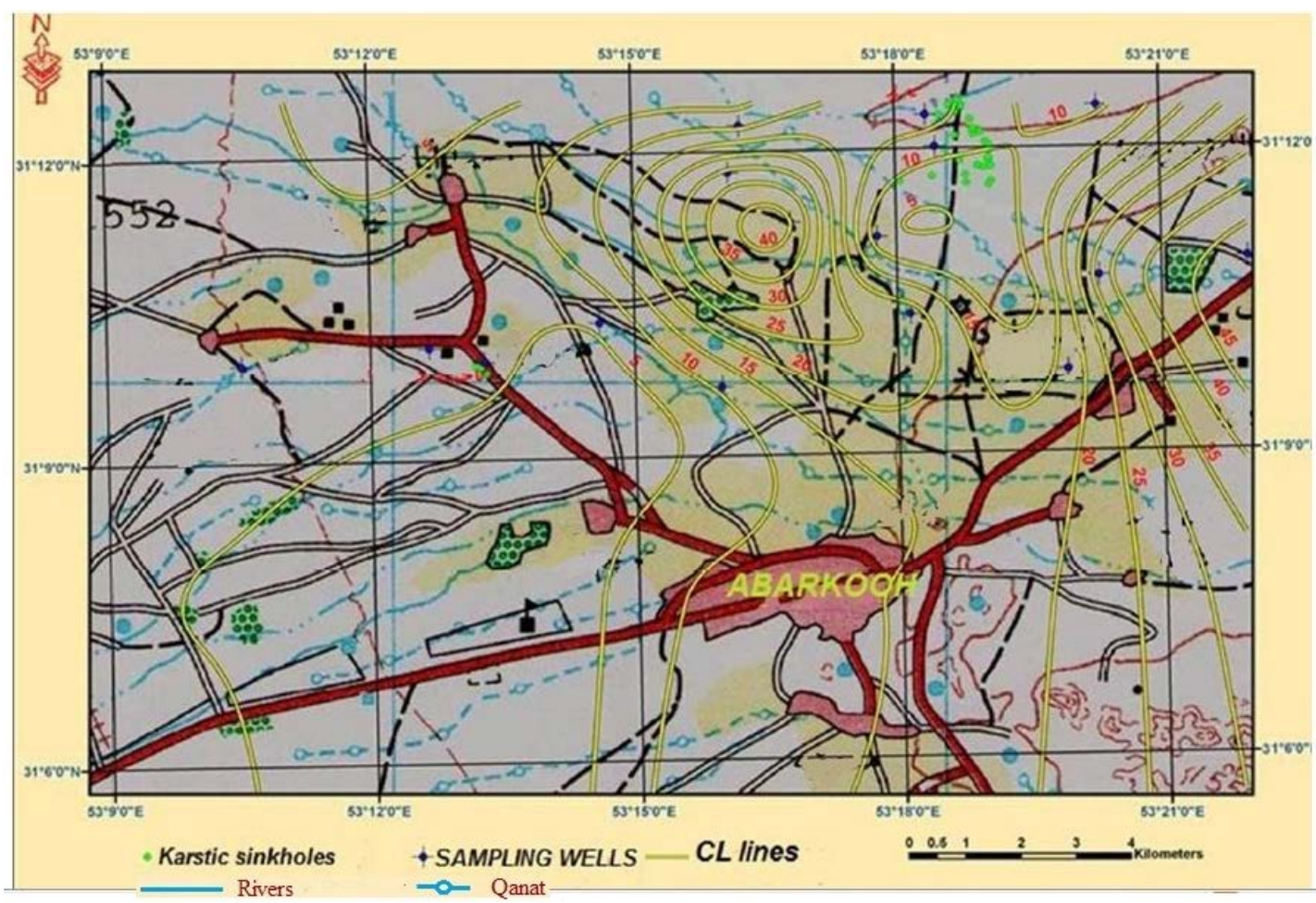

Figure 14. Contour lines of the chloride concentrations in groundwater in $\mathrm{mg} / \mathrm{L}$ in the Abarkooh plain. 


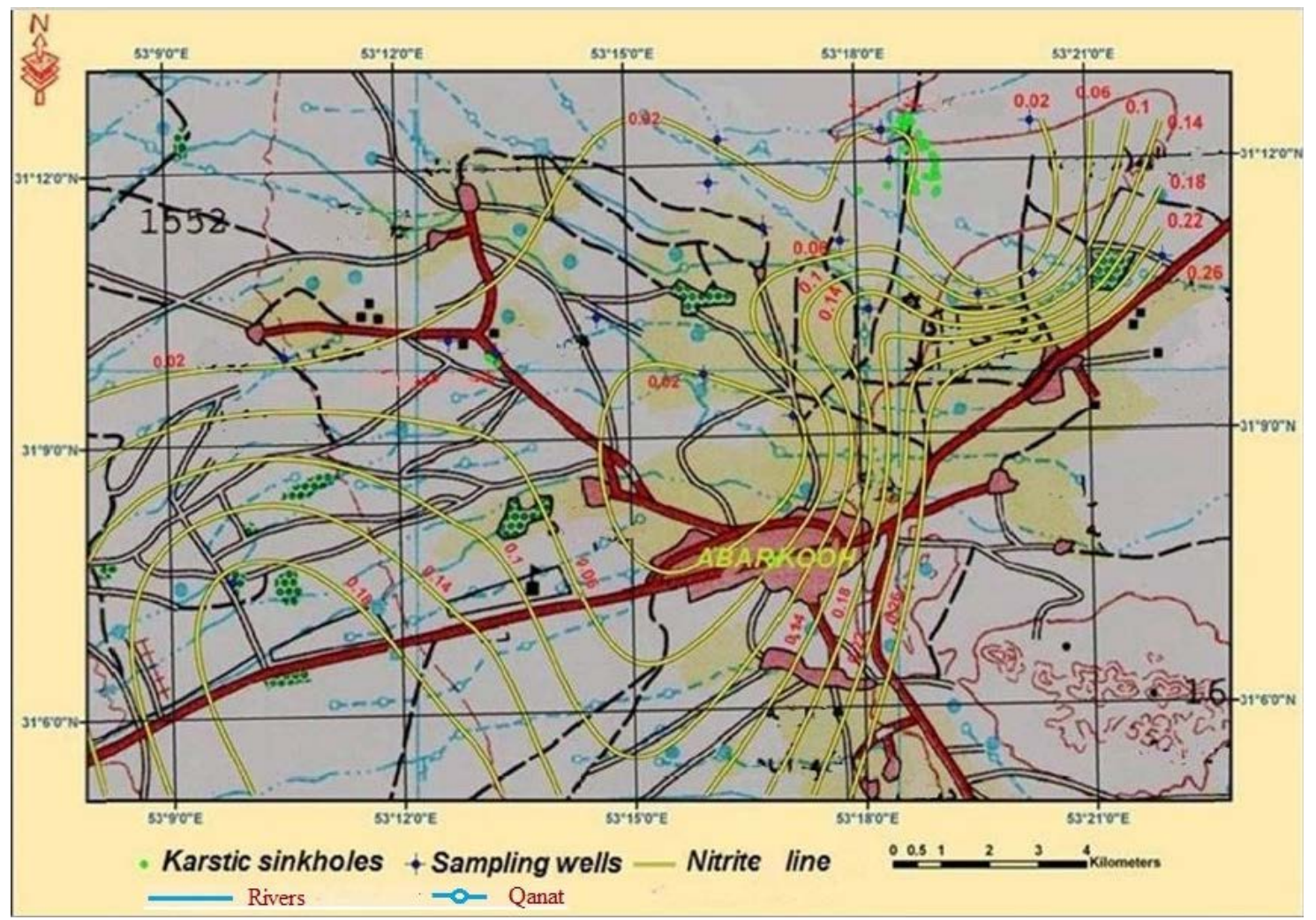

Figure 15. Contour lines of the nitrite concentrations in groundwater in $\mathrm{mg} / \mathrm{L}$ in the Abarkooh plain.

Table 1. Chemical analysis of selected wells in the Abarkooh plain.

\begin{tabular}{|c|c|c|c|c|c|c|c|c|c|c|c|c|c|c|c|}
\hline & \multirow{2}{*}{$x$} & \multirow{2}{*}{$Y$} & \multirow{2}{*}{$\begin{array}{l}\text { Well } \\
\text { Name }\end{array}$} & \multicolumn{12}{|c|}{$\mathrm{mEq} / \mathrm{L}$} \\
\hline & & & & $\mathrm{CO}_{2}$ & $\mathrm{HCO}_{3}$ & $\mathrm{CL}$ & $\mathrm{SO}_{4}$ & $\mathrm{NO}_{3}$ & $\mathrm{NO}_{2}$ & SUM AN. & $\mathrm{Ca}$ & $\mathrm{Mg}$ & $\mathrm{Na}$ & K & SUM CAT. \\
\hline 1 & 701,619 & $3,441,155$ & W81 & 0.4 & 2.9 & 8.75 & 7 & 0.001 & 0.49 & 19.54 & 5.00 & 5.00 & 10.63 & 0.06 & 20.69 \\
\hline 2 & 706,294 & $3,445,451$ & W82 & 0.4 & 2.3 & 5 & 4 & 0.004 & 0.29 & 11.99 & 3.00 & 2.00 & 7.60 & 0.04 & 12.64 \\
\hline 3 & 707,344 & $3,450,046$ & W83 & 0.4 & 2.3 & 5.95 & 2.5 & 0.000 & 0.25 & 11.40 & 2.50 & 2.30 & 7.16 & 0.04 & 12.00 \\
\hline 4 & 710,733 & $3,450,391$ & W84 & 0.4 & 2.3 & 6.1 & 3.5 & 0.001 & 0.22 & 12.52 & 2.30 & 2.90 & 7.60 & 0.05 & 12.85 \\
\hline 5 & 711,721 & $3,450,145$ & W85 & 0.4 & 2.3 & 6.35 & 3 & 0.001 & 0.22 & 12.27 & 2.50 & 2.30 & 9.77 & 0.05 & 14.62 \\
\hline 6 & 713,794 & $3,450,871$ & W86 & 0.4 & 2.8 & 6.25 & 7.5 & 0.001 & 0.26 & 17.21 & 4.20 & 3.40 & 8.02 & 0.04 & 15.66 \\
\hline 7 & 716,024 & $3,449,697$ & W87 & 0.4 & 2.2 & 10.75 & 5.5 & 0.000 & 0.40 & 19.25 & 3.60 & 5.20 & 11.06 & 0.04 & 19.90 \\
\hline 8 & 717,857 & $3,448,835$ & W88 & 0.2 & 1.8 & 15.15 & 5 & 0.000 & 0.21 & 22.36 & 4.60 & 7.40 & 13.62 & 0.07 & 25.69 \\
\hline 9 & 719,433 & $3,451,052$ & W89 & 0.2 & 1.7 & 22 & 8 & 0.004 & 0.27 & 32.17 & 5.50 & 7.00 & 20.40 & 0.07 & 32.97 \\
\hline 10 & 721,704 & $3,451,367$ & W810 & 0.6 & 2.7 & 9.5 & 2.25 & 0.001 & 0.09 & 15.14 & 3.00 & 2.00 & 10.42 & 0.07 & 15.49 \\
\hline 11 & 722,819 & $3,451,785$ & W811 & 0.4 & 2.8 & 31.75 & 10 & 0.001 & 0.33 & 45.28 & 5.50 & 9.50 & 28.64 & 0.09 & 43.73 \\
\hline 12 & 722,748 & $3,454,874$ & W812 & 0.8 & 3.1 & 8.85 & 2.5 & 0.000 & 0.12 & 15.37 & 2.70 & 3.30 & 9.98 & 0.08 & 16.06 \\
\hline 13 & 719,862 & $3,454,095$ & W813 & 0.6 & 2.7 & 11.5 & 2.5 & 0.001 & 0.13 & 17.43 & 3.00 & 4.50 & 13.00 & 0.07 & 20.57 \\
\hline 14 & 719,683 & $3,454,674$ & W814 & 0 & 3.4 & 16.5 & 2.95 & 0.000 & 0.05 & 22.90 & 4.40 & 6.10 & 13.75 & 0.07 & 24.32 \\
\hline 15 & 716,311 & $3,454,463$ & W815 & 0 & 4.7 & 13.65 & 4 & 0.000 & 0.08 & 22.43 & 5.00 & 6.00 & 12.17 & 0.07 & 23.24 \\
\hline 16 & 716,114 & $3,453,602$ & W816 & 0.4 & 3 & 31.45 & 12 & 0.001 & 0.42 & 47.27 & 5.20 & 8.30 & 32.98 & 0.14 & 46.62 \\
\hline 17 & 717,250 & $3,452,895$ & W817 & 0 & 3.5 & 40.25 & 13.75 & 0.001 & 0.48 & 57.98 & 8.20 & 9.90 & 42.60 & 0.15 & 60.85 \\
\hline 18 & 725,508 & $3,452,123$ & W818 & 0.8 & 3.1 & 48.25 & 5.5 & 0.001 & 0.17 & 57.83 & 3.20 & 4.80 & 50.34 & 0.20 & 58.54 \\
\hline 19 & 722,267 & $3,450,067$ & W819 & 0.6 & 2.7 & 17.25 & 5.5 & 0.006 & 0.21 & 26.26 & 4.00 & 5.00 & 16.05 & 0.07 & 25.12 \\
\hline 20 & 718,828 & $3,452,441$ & W820 & 0.6 & 2.6 & 7.75 & 2.75 & 0.001 & 0.12 & 13.82 & 2.50 & 2.50 & 10.45 & 0.09 & 15.54 \\
\hline
\end{tabular}


Table 2. Chemical analysis of selected wells in the Abarkooh plain.

\begin{tabular}{|c|c|c|c|c|c|c|c|c|c|c|c|}
\hline & \multirow{2}{*}{$X$} & \multirow{2}{*}{$Y$} & \multirow{2}{*}{$\begin{array}{c}\text { Well } \\
\text { Name }\end{array}$} & \multicolumn{3}{|c|}{$\mathrm{Mg} / \mathrm{L}$} & \multicolumn{3}{|l|}{$\%$} & \multicolumn{2}{|l|}{$\mu \mathrm{m} / \mathrm{cm}$} \\
\hline & & & & T.D.S. & T.H & ALK & $\mathrm{Na} \%$ & SAR & PH & EC & ERROR \\
\hline 1 & 701,619 & $3,441,155$ & W81 & 1242.00 & 500.00 & 165.00 & 51.00 & 4.75 & 8.31 & 1864.00 & -2.85 \\
\hline 2 & 706,294 & $3,445,451$ & W82 & 782.00 & 250.00 & 135.00 & 60.00 & 4.81 & 8.41 & 1165.00 & -2.64 \\
\hline 3 & 707,344 & $3,450,046$ & W83 & 727.00 & 240.00 & 135.00 & 60.00 & 4.62 & 8.46 & 1166.00 & -2.55 \\
\hline 4 & 710,733 & $3,450,391$ & W84 & 749.00 & 260.00 & 135.00 & 59.00 & 4.71 & 8.46 & 1227.00 & -1.30 \\
\hline 5 & 711,721 & $3,450,145$ & W85 & 826.00 & 240.00 & 135.00 & 67.00 & 6.31 & 8.46 & 1177.00 & -8.73 \\
\hline 6 & 713,794 & $3,450,871$ & W86 & 1075.00 & 380.00 & 160.00 & 51.00 & 4.11 & 8.36 & 1562.00 & 4.71 \\
\hline 7 & 716,024 & $3,449,697$ & W87 & 1182.00 & 440.00 & 130.00 & 56.00 & 5.27 & 8.39 & 1872.00 & -1.67 \\
\hline 8 & 717,857 & $3,448,835$ & W88 & 1390.00 & 600.00 & 100.00 & 53.00 & 5.56 & 8.35 & 2252.00 & -6.92 \\
\hline 9 & 719,433 & $3,451,052$ & W89 & 1941.00 & 625.00 & 95.00 & 62.00 & 8.16 & 8.31 & 3145.00 & -1.23 \\
\hline 10 & 721,704 & $3,451,367$ & W810 & 954.00 & 250.00 & 165.00 & 67.00 & 6.59 & 8.56 & 1514.00 & -1.14 \\
\hline 11 & 722,819 & $3,451,785$ & W811 & 2676.00 & 750.00 & 160.00 & 65.00 & 10.46 & 8.33 & 4388.00 & 1.74 \\
\hline 12 & 722,748 & $3,454,874$ & W812 & 974.00 & 300.00 & 195.00 & 62.00 & 5.76 & 8.66 & 1480.00 & -2.21 \\
\hline 13 & 719,862 & $3,454,095$ & W813 & 1127.00 & 375.00 & 165.00 & 63.00 & 6.71 & 8.55 & 1747.00 & -8.27 \\
\hline 14 & 719,683 & $3,454,674$ & W814 & 1415.00 & 525.00 & 170.00 & 57.00 & 6.00 & 8.24 & 2343.00 & -3.00 \\
\hline 15 & 716,311 & $3,454,463$ & W815 & 1418.00 & 550.00 & 235.00 & 52.00 & 5.19 & 8.06 & 2232.00 & -1.77 \\
\hline 16 & 716,114 & $3,453,602$ & W816 & 2855.00 & 675.00 & 170.00 & 71.00 & 12.69 & 8.33 & 4686.00 & 0.69 \\
\hline 17 & 717,250 & $3,452,895$ & W817 & 3571.00 & 905.00 & 175.00 & 70.00 & 14.16 & 8.25 & 5727.00 & -2.41 \\
\hline 18 & 725,508 & $3,452,123$ & W818 & 3477.00 & 400.00 & 195.00 & 86.00 & 25.17 & 8.58 & 5824.00 & -0.61 \\
\hline 19 & 722,267 & $3,450,067$ & W819 & 1571.00 & 450.00 & 165.00 & 64.00 & 7.57 & 8.50 & 2578.00 & 2.22 \\
\hline 20 & 718,828 & $3,452,441$ & W820 & 908.00 & 250.00 & 160.00 & 67.00 & 6.61 & 8.57 & 1336.00 & -5.86 \\
\hline
\end{tabular}

\section{Conclusions and Recommendations}

The existence of the sinks in Feizabad region is a sign of transportation of surface waters into the gaps and deep cracks of the bedrock and eventually into the groundwater aquifer. The surface water level dropped to $15.3 \mathrm{~m}$ during 25 years. Artificial recharges, which controls the river flows by embankments and concentrate the surface waters, were the major causes of the occurrence of the sinkholes, together with the existence of faults and cracks of bedrock. The existence of limestone bedrock with faults and cracks in the north part of the plain and around Abarkooh City has the potential for development of future sinkholes. The flows of the rivers make the north part of the Abarkooh plain more vulnerable, so any activity that causes the inertia and increase of infiltration of surface water is dangerous. The northern part of the Abarkooh plain and Abarkooh city have more deep fractures (critical area), which implies that the possibility of the occurrence of sinkholes are higher in these areas. In the central and southeastern areas of the Abarkooh plain, increase in electrical conductivity is observed, while in the north east region (District Feizabad) there is a significant decrease in electrical conductivity.

It seems that the role of sinkholes in the aquifer recharge prevents the increase in electrical conductivity from the west to the east. Building of embankments and development of sinkholes (in order to recharge the aquifer) led to the changing of the trend of increasing of electric conductivity in the region. Lines of chloride, nitrate and nitrite show that there is a decreasing of water quality in Feizabad due to recharge from sinkholes.

With regards to the provided analysis, recommendations for removing and preventing the deterioration of drinking water quality are: 
1-Reducing the occurrence of sinkholes in the region and mapping of critical areas of risk and prevention of environmental pollution;

2-Any artificial recharge operation and creation of embankments and basin should be stopped;

3-Changing the regional pattern of flood irrigation to the drip method and controlling the exploitation to prevent the infiltration and concentration of water into farms;

4-Application of geophysical methods and the use of ground penetrating radar (GPR), electromagnetic geophysical survey (EMS) and seismic gravimetric methods order to identify the critical areas;

5-Prevention of waste dumping in sinkholes;

6-Groundwaterflow tracing from the location of the sinkholes to determine the relationships between groundwater flow and its effect on the exploitation wells;

7-Prevention from digging the wells and drilling in critical areas;

8-Wells that have higher discharge and have entered the bedrock should be controlled or shut down.

Author Contributions: Conceptualization, B.S., S.M.S. and A.A.; methodology, B.S., S.M.S.; validation, B.Đ.; formal analysis, B.Đ.; investigation, A.A. and S.M.S.; resources, S.M.S.; data curation, B.Đ.; writing-original draft preparation, A.A.; visualization, B.S.; funding acquisition, B.S. please turn to the CRediT taxonomy for the term explanation. Authorship must be limited to those who have contributed substantially to the work reported. All authors have read and agreed to the published version of the manuscript.

Funding: The APC was funded by the Office of Certified Civil Engineer Božo Soldo, Vinka Mederala 4b, 42000 Varaždin, Croatia.

Acknowledgments: Publication process is supported by the Office of Certified Civil Engineer Božo Soldo, Vinka Mederala 4b, 42000 Varaždin, Croatia.

Conflicts of Interest: The authors declare no conflict of interest. The funders had no role in the design of the study; in the collection, analyses, or interpretation of data; in the writing of the manuscript, or in the decision to publish the results.

\section{References}

1. United States Geological Survey (USGS). Available online: https://www.usgs.gov/faqs/what-are-sinkholes? qt-news_science_products=0\#qt-news_science_products (accessed on 3 January 2018).

2. Waltham, A.C.; Fookes, P.G. Engineering classification of karst ground conditions. Q. J. Eng. Geol. Hydrogeol. 2003, 36, 101-118. [CrossRef]

3. Masciopinto, C.; De Giglio, O.; Scrascia, M.; Fortunato, F.; La Rosa, G.; Suffredini, E.; Pazzani, C.; Prato, R.; Montagna, M.T. Human health risk assessment for the occurrence of enteric viruses in drinking water from wells: Role of flood runoff injections. Sci. Tot. Environ. 2019, 666, 559-571. [CrossRef] [PubMed]

4. Ford, D.C.; Williams, P.W. Karst Geomorphology and Hydrology; Springer: London, UK, 1989; p. 601.

5. Barry, F.; Beck, A.J. Hydrogeology and Engineering Geology of Sinkholes and Karst; Balkema: Rotterdam, The Netherlands, 1999.

6. Beck, B.F. Sinkholes and the Engineering and Environmental Impacts of Karst; The American Society of Civil Engineers: San Antonio, TX, USA, 2005.

7. Naseri, H.R. Hydrogeological Study of Karst Springs of Durudzan dam Catchment Area. Master's Thesis, Shiraz University, Shiraz, Iran, 1991; p. 315.

8. Khanlari, G.R.; Heidari, M.; Momeni, A.A.; Ahmadi, M.; Taleb-Beydokhti, A. The effect of groundwater over exploitation on land subsidence and sinkhole occurrences, Western Iran. Q. J. Eng. Geol. Hydrogeol. Iran 2012, 45, 447-456. [CrossRef]

9. Karimi, H.; Taheri, K. Hazards and mechanism of sinkholes on Kabudar Ahang and Famenin plains of Hamadan, Iran. Nat. Hazards 2010, 55, 481-499. [CrossRef]

10. Belfar, D.; Fehdi, C.; Baali, F.; Salameh, E. Results of a hydrogeological and hydrogeochemical study of a semi-arid karst aquifer in Tezbent plateau, Tebessa region, northeast of Algeria. Appl. Water Sci. 2017, 7, 1099-1105. [CrossRef]

11. Gillieson, D.S.; Cochrane, J.A.; Murray, A. Surface hydrology and soil movement in an arid karst: The Nullarbor Plain, Australia. Environ. Geol. 1994, 23, 125-133. [CrossRef] 
12. Ahmad Dar, F.; Perrin, J.; Riotte, J.; Daniel Gebauer, H.; Chinna Narayana, A.; Ahmed, S. Karstification in the Cuddapah Sedimentary Basin, Southern India: Implications for Groundwater Resources. Acta Carsologica 2011, $40,3$.

13. Zheng, X.; Zang, H.; Zhang, Y.; Chen, J.; Zhang, F.; Shen, Y. A Study of Hydrogeochemical Processes on Karst Groundwater Using a Mass Balance Model in the Liulin Spring Area, North China. Water 2018, 10, 903. [CrossRef]

14. Yousif, M.; Oguchi, T.; Anazawa, K.; Takeshi, O. Framework for Investigation of Karst Aquifer in an Arid Zone, Using Isotopes, Remote Sensing and GIS Applications: The Northwestern Coast of Egypt. Environ. Process 2015, 2, 37-60. [CrossRef]

15. Karimi Vardanjani, H.; Chitsazan, M.; Ford, D.; Karimi, H.; Charchi, A. Initial assessment of recharge areas for large karst springs: A case study from the central Zagros Mountains, Iran. Hydrogeol. J. 2018, 26, 57-70. [CrossRef]

16. Pazand, K.; Khosravi, D.; Ghaderi, M.R.; Rezvanianzadeh, M.R. Identification of the hydrogeochemical processes and assessment of groundwater in a semi-arid region using major ion chemistry: A case study of Ardestan basin in Central Iran. Groundw. Sustain. Dev. 2018, 6, 245-254. [CrossRef]

17. Xanke, J. Managed Aquifer Recharge into a Karst Groundwater System at the Wala Reservoir, Jordan. Ph.D. Thesis, Karlsruher Institute fur Technologie, Karlsruhe, Germany, 2017.

18. Taheri, K.; Gutiérrez, F.; Mohseni, H.; Raeisi, E.; Taheri, M. Sinkhole susceptibility mapping using the analytical hierarchy process (AHP) and magnitude-frequency relationships: A case study in Hamadan province, Iran. Geomorphology 2015, 234, 64-79. [CrossRef]

19. Taheri, K.; Shahabi, H.; Chapi, K.; Shirzadi, A.; Gutiérrez, F.; Khosravi, K. Sinkhole susceptibility mapping: A comparison between Bayes-based machine learning algorithms. Land Degrad. Dev. 2019, 37, 730-745. [CrossRef]

20. Perrin, J.; Cartannaz, C.; Noury, G.; Vanoudheusden, E. A multicriteria approach to karst subsidence hazard mapping supported by weights-of-evidence analysis. Eng. Geol. 2015, 197, 296-305. [CrossRef]

21. Mahmoudi Sivand, S. Yazd Province Authority. Meteorological Data; Iran karst research center: Shiraz, Iran, 2011.

22. Google Maps. Available online: www.google.com (accessed on 2 February 2020).

23. Mahmoudi Sivand, S. Official report about hydrogeological, hydrogeochemistry and geophysical investigation at Feizabad site. Available online: www.yzrw.ir (accessed on 1 August 2016).

24. Waltham, F.B. Sinkholes and Subsidence, Karst and Cavernous Rocks in Engineering and Construction; Praxis Publishing: Chichester, UK, 2005.

25. United States Environmental Protection Agency [US EPA]. 2018 Edition of the Drinking Water Standards and Health Advisories Tables. Available online: www.epa.gov (accessed on 5 March 2018). 